\title{
Using Inter-canine Width for Arch Length Prediction in Jaipur Population
}

\author{
Dr.Vikas K. Soni ${ }^{1}$, Dr. Shami Soni ${ }^{2}$, Dr. Rajesh Agarwal ${ }^{3}$, Dr. Shilpa Agarwal ${ }^{4}$, \\ Dr. Hardik ${ }^{5}$, Dr. Kruti ${ }^{6}$ \\ P.G. Student ${ }^{1,5,6}$, Professor \& $\mathrm{Head}^{2}$, Professor ${ }^{3}$, \\ Department of orthodontics \& Dentofacial OrthopaedicsJaipur Dental College, Jaipur, Rajasthan (India) \\ Professor $^{4}$ \\ Department of Endodontics\& Conservative Dentistry, Jaipur Dental College, Jaipur, Rajasthan (India)
}

\begin{abstract}
Arch length, inter-canine width, and inter-molar width are essential for diagnosisand treatment planning and are closely related factors in orthodontics.

Aim:The aim of the present study was used to determine correlations between these measurements and to predict some of these measurements based on others.

Method:The dental casts of 30 patients (15 females and 15 males) with a mean age of 18 years (11-26 years) in the permanent dentition attending the Orthodontic Department of the Jaipur Dental College, Jaipur,were selected. Intercanine width, intermolar width, and arch length on each dental cast were measured. Correlation between variables was determined using Pearson's correlation coefficient. Linearregression analysis was applied and the 95 per cent confidence intervals for slope and interceptwere determined.

Result: The data showed very high correlations between inter-canine width and arch length, both for the upper and lower arches and for males and females, $r=0.925$. This coefficient was very close to 1, indicating a linear relationship.The regression equation for arch length and inter-canine width was arch length $=1.36$ inter-canine width +29.39 for both arches.

Conclusion: There was very high correlations between arch length and inter-canine width for the upper and lower arches and a regression equation between both magnitudes was established indicating that the size of one factor can be predicted by knowing the other. For an increase of $1 \mathrm{~mm}$ in inter-canine width, the arch length increases approximately $1.36 \mathrm{~mm}$ with a 95 per cent confidence intervals $(1.30-1.42)$.
\end{abstract}

Key Words: Arch length, inter-canine width, inter-molar width.

\section{Introduction}

There are several methods for determining the resulting loss of arch circumference. One popular rule of thumb for estimating the resulting loss of arch circumference is that $1 \mathrm{~mm}$ of arch circumference is needed for each millimeterof curve of Spee depth present. Baldridgeand Garcia found the ratio to be more accurately expressed by the formulas $\mathrm{Y}=0.488 \mathrm{X}-0.51$ and $\mathrm{Y}=0.657 \mathrm{X}+1.34$, respectively, where $\mathrm{Y}$ is the arch length differential in millimeters and $\mathrm{X}$ is the sum of right and left side maximum depths of the curve of Spee in millimeters. In a mathematical model, Germane et al. determined the relationship to be non-linear, and the arch circumference differential less than a one-to-one ratio for curves of Spee having a depth of $9 \mathrm{~mm}$ or less.

As the natural maxillary and mandibular arch-forms have recently been accurately described by themathematical beta function with a correlation coefficient $(r)$ of 0.98 , it is the objective of this study to predict the correlation between arch length, inter-canine width, and inter-molar width measurementsand to predict some of these measurements based on others.

\section{Sample selection:-}

\section{Materials and Methods}

The sampleconsisted of 30 dental casts of patients obtained from patients who underwent fixed orthodontic treatment at the Orthodontic Department of the Jaipur Dental College, Jaipur.

The inclusion and exclusion criteria of the sample selection were as follows:-

1. A permanent dentition from second molar to second molar;

2. Well aligned arches with tight contacts and no crowding was present

3. Either all first premolars or second premolars or a combination of first and second premolars were extracted

Prior to treatment.

4. Pre \& Post treatment dental casts of appropriate quality be available for all the selected samples;

5. No tooth agenesis or itshould be without trauma \& any Anomalous shape

6. No large restorations/grossly decayed tooth that could change the mesio-distal diameters of the teeth; 


\section{Measurement procedure:-}

The mesio-distal sizes of the upper and lower teeth of each cast, excluding the second and third molars when they were present, were measured by the investigator and then all the sample casts were re-labelled in order to obtain concrete results. The sample casts was also measured by another investigator and he was blind folded for the previously obtained results. Upper and lower inter-canine widths (maximum linear width between thecanines), upperand lower inter-molar widths (maximum linear width between molarsat their buccal surface), upperand lower arch lengths (ideal line between every mesial and distalcontact point of each permanent tooth from the mesial ofthe first molar to the mesial of the first molar of the oppositeside) were measured (Figure 1). Arch-lengthwas considered to be equal to arch perimeter.

All these casts were re-measured by both the investigators after a period of 1 week and the final value was obtained by taking a mean of all the measurements.

\section{Results}

A high correlation was observed between upper arch lengths and upper inter-canine widthsas well as between lower arch lengthsand lower inter-canine widths, while a weak correlationwas found between upper arch lengths and upper inter-molar widths and lower arch lengthsand lower inter-molar widths.

The regression parameters are shown in Table1. The correlation coefficient between arch-length and inter-canine widths, $r=0.925$, showed a very good linear relationship between variables, making it possible to establish the following regression equation for upper arch lengths and lower arch lengths and upper inter-canine widths and lower inter-canine widths:

Arch length $=1.36 \times$ Inter-canine width +29.39 .

The 95 per cent confidence interval for the slope $(1.30$ - 1.41) means thatfor each millimeter of inter-canine width increase, the arch-length would increasebetween 1.30 and $1.41 \mathrm{~mm}$.

A low correlation between upper arch lengths and upper inter-molar widths $(r=0.474)$ and between lower archlengths and lower inter-molar widths $(r=0.426)$ wasfound, indicating that there was no linear correlation.

\begin{tabular}{|l|l|l|l|l|c|}
\hline Variables & $\begin{array}{l}\text { Regression } \\
\text { parameters }\end{array}$ & Values & Standarderror & $\begin{array}{l}\text { 95 per cent confidence } \\
\text { Interval } \\
\text { Lowerlimit/Upperlimit }\end{array}$ & $\begin{array}{l}\text { Pearson's } \\
\text { coefficient }\end{array}$ \\
\hline \multirow{2}{*}{$\begin{array}{l}\text { AL } \\
\text { versus } \\
\text { ICW }\end{array}$} & Slope & 1.360 & 0.028 & $27.679 / 31.094$ & 0.925 \\
\cline { 2 - 5 } & Intercept & 29.386 & 0.869 & $1.305 / 1.416$ & \\
\hline
\end{tabular}

Table 1 Linear regression parameters for arch length (AL) versusinter-canine width (ICW) (upper and lower).

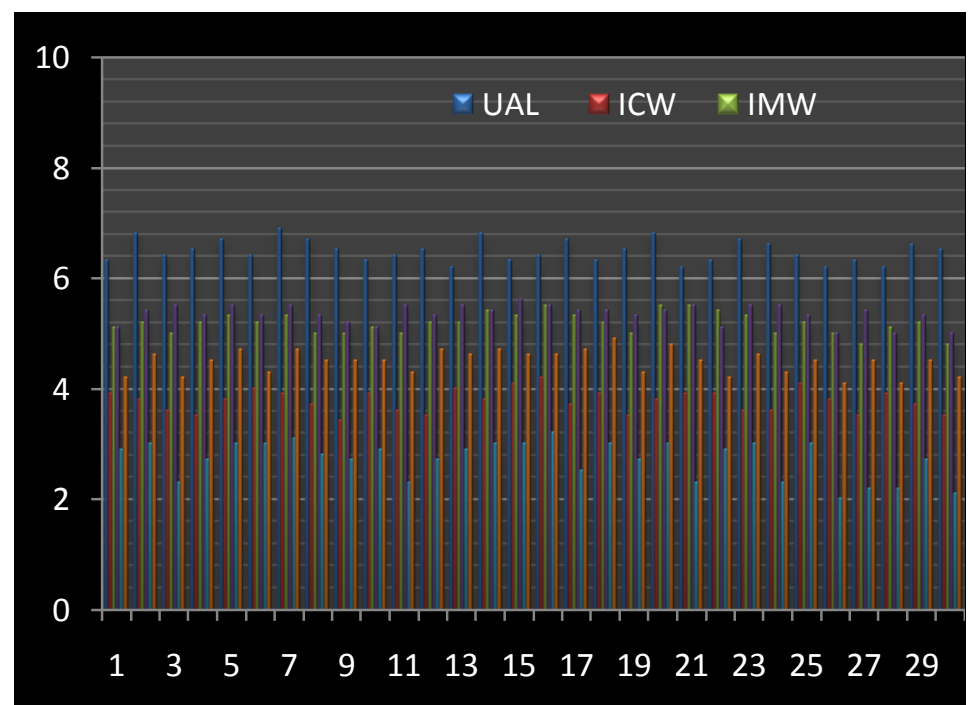

Figure 2. Correlation between upper arch length, inter-canine width and inter-molar width. 


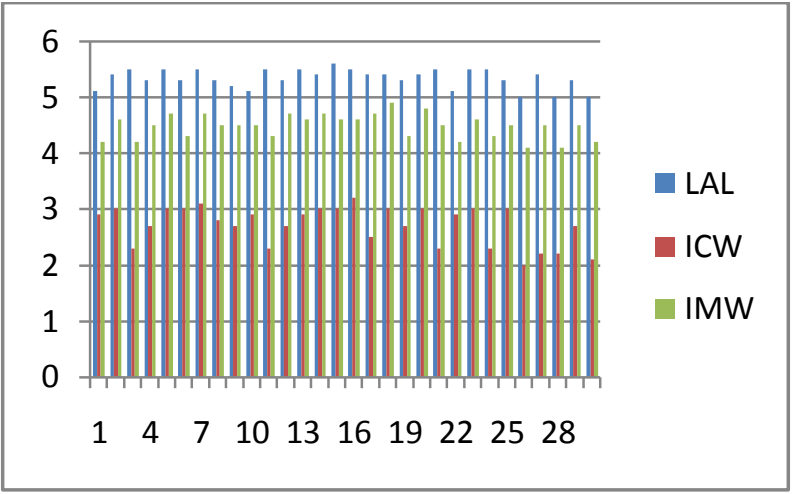

Figure 3. Correlation between lower arch length, inter-canine width and inter-molar width.

\section{Conclusions}

A high correlation coefficient between arch-length and inter-caninewidth was found for both arches, and a regression equation was established between both magnitudes. Correlation makes it possible to predict the size of one of the variables by knowing the size of the other. The correlations between inter-molarwidth and arch-length were lower and with a differing variation between the upper and the lower arch. For an increase of 1 $\mathrm{mm}$ of inter-canine width, the arch-length increases approximately $1.36 \mathrm{~mm}$ with 95 per cent confidence interval $(1.30-1.42)$.

\section{$\underline{\text { References }}$}

[1]. Adkins MD, Nanda RS , Currier GF 1990 Arch perimeter changes on rapid palatal expansion .Am J OrthodDentofacialOrthop 97 : $194-199$

[2]. Germane N, Lindauer SJ, Rubenstein LK, Revere JH, Isaacson RJ1991 Increase in arch perimeter due to orthodontic expansion.Am J OrthodDentofacialOrthop $100: 421-427$

[3]. Hnat WP, Braun S, Chinhara A, Legan HL 2000 The relationship of arch length to alterations in dental arch width . Am J OrthodDentofacialOrthop $118: 184-188$

[4]. Motoyoshi M, Hirabayashi M, Shimazaki T, Namura S 2002 An experimental study on mandibular expansion: increases in arch width and perimeter .Eur J Orthod $24: 125-130$

[5]. Paredes V, Gandía JL , Cibrian RM 2005 New, fast and accurate procedure to calibrate a 2-dimensional digital measurement method.Am J OrthodDentofacial Orthop127:518 - 519 